\title{
Application Of Logistic Regression In Analysis Of Factors That Affect Implementation Of Electronic Medical Record
}

\author{
Agung Purwo Wicaksono ${ }^{a^{*}}$, Kariyam $^{\mathrm{b}}$, Izzati Muhimmah \\ ${ }^{a}$ Program Pascasarjana Magister Informatika, Universitas Islam Indonesia, Yogyakarta \\ ${ }^{\mathrm{b}}$ Program Studi Statistika, Universitas Islam Indonesia, Yogyakarta \\ ${ }^{c}$ Program Pascasarjana Magister Informatika, Universitas Islam Indonesia, Yogyakarta \\ e-mail:pewe3324@gmail.com
}

\begin{abstract}
Electronic Medical Record (EMR) has now become a trend in the world of health care. Lot of obstacles and barriers that interfere implementation of EMR. This paper discussed the eleven factors suspected to affect the implementation of EMR, with a case study hospital in Banyumas. By using logistic regression analysis obtained eight of the eleven factors that significantly affect the implementation of RME. The eight factors are financial factors, Human Resources (HR), the process of changing, psychological factors, legal factors, the time factor, organizational factors, and ICT trends. Technology, infrastructure, and social is a factor that does not significantly affect the implementation of EMR in hospital. ICT trends are new factors that significantly affect the implementation of EMR in hosital.
\end{abstract}

Keywords : EMR, logistic regression, Banyumas, ICT trends, health care

\begin{abstract}
ABSTRAK
Salah satu penggunaan Teknologi Informasi dan Komunikasi (TIK) dalam dunia kesehatan yang telah menjadi tren dalam dunia pelayanan kesehatan secara global adalah Rekam Medis Elektronik (RME). Pada bagian lain berbagai macam kendala dan hambatan yang berpotensi untuk dapat mengganggu terwujudnya program tersebut tidaklah sedikit. Pada makalah ini dibahas sebelas faktor yang diduga mempengaruhi implementasi RME, dengan mengambil studi kasus Rumah Sakit (RS) di Kabupaten Banyumas. Dengan menggunakan analisis regresi logistik didapatkan delapan dari sebelas faktor yang signifikan berpengaruh terhadap implementasi RME. Adapun kedelapan faktor tersebut adalah: faktor finansial, faktor Sumber Daya Manusia (SDM), faktor proses perubahan, faktor psikologi, faktor legal, faktor waktu, faktor organisasi, dan tren TIK. Faktor teknologi, infrastruktur, dan sosial adalah faktor yang tidak signifikan berpengaruh terhadap implementasi RME di RS. Faktor tren TIK merupakan faktor baru yang secara signifikan berpengaruh terhadap implementasi RME di RS.
\end{abstract}

Kata Kunci : RME, regresi logistik, Banyumas, tren TIK, layanan kesehatan

\section{Pendahuluan}

Rekam medis adalah kumpulan keterangan tentang identitas, hasil anamnesis, pemeriksaan, dan catatan segala kegiatan para pelayan kesehatan atas pasien dari waktu ke waktu. Catatan ini bisa bersifat cetakan ataupun data digital (Hanafiah dan Amir, 1999).
Di Indonesia RME sebenarnya telah mulai bergema sejak tahun 2005. Pemerintah sebagai salah satu stakeholder yang berperan sangat penting melalui Kementerian Kesehatan bekerjasama dengan Kementerian Komunikasi dan Informatika sudah sejak awal tahun 2005 mencanangkan program 
layanan kesehatan terintegrasi (e-health Indonesia) dengan tujuan untuk mewujudkan pemerataan layanan kesehatan bagi seluruh wilayah di Indonesia khususnya daerah yang selama ini sangat sulit dijangkau oleh treatment kesehatan yang berkualitas serta teknologi penunjang sarana kesehatan. Program yang dicanangkan oleh dua kementrian tersebut merupakan angin segar bagi perbaikan kualitas layanan kesehatan di Indonesia. Akan tetapi berbagai macam kendala dan hambatan yang berpotensi untuk dapat mengganggu terwujudnya program tersebut tidaklah sedikit (Djalil, 2005).

Benson (2011) dengan menggunakan mix method statistic dalam penelitiannya mengungkapkan bahwa faktor finansial, teknologi, psikologis, dan legal formal adalah faktor yang berpengaruh secara signifikan dalam implementasi RME pada RS. Dengan menggunakan multiple regression analysis, Butt dkk (2014) menemukan bahwa faktor finansial, SDM, waktu, psikologis, sosial, legal formal, organisasi, dan proses perubahan merupakan faktor yang signifikan terhadap implementasi RME. Dari penelusuran literatur yang lain, ditemukan 10 faktor yang memiliki pengaruh dalam implementasi RME pada RS, yaitu (1) finansial, (2) SDM, (3) teknologi, (4) infrastruktur, (5) waktu, (6) psikologis, (7) sosial, (8) legal formal, (9) organisasi, dan (10) proses perubahan (Boonstra dan Broekhuis, 2010; Granlien dan Hertzum, 2012; Handiwidjojo, 2009; Hassan, dkk., 2010; Hasanain dan Cooper, 2014; Khalifa, 2013).

Subkhan (2011), mengatakan bahwa saat ini tren TIK telah mempengaruhi dunia pendidikan. Demikian pula seperti yang disampaikan oleh kantor kominfo Kota Bogor mengatakan bahwa fungsi teknologi informasi tidak sekedar sebagai penunjang manajemen pemerintahan yang ada, tetapi justru merupakan sebagai hal yang justru menawarkan terjadinya perubahan-perubahan mendasar sehubungan dengan proses penyelenggaraan pemerintahan (Pemerintah Kota Bogor, 2013).

Berdasarkan uraian diatas maka pada penelitian ini akan diteliti apakah faktor finansial, SDM, infrastruktur, waktu, psikologis, sosial, legal formal, organisasi, proses perubahan, dan tren TIK berpengaruh terhadap implementasi RME pada RS dengan menggunakan metode analisis regresi logistik. Penelitian ini mengambil studi kasus pada RS di Kabupaten Banyumas.

\section{Tujuan Penelitian/Tujuan Penulisan}

Tujuan yang ingin dicapai dalam penelitian ini adalah: 
1. Untuk mengetahui faktor-faktor yang secara statistik berpengaruh terhadap implementasi RME pada RS di Kabupaten Banyumas dengan menggunakan analisis regresi logistik.

2. Untuk membuktikan bahwa tren TIK secara statistik juga berpengaruh terhadap implementasi RME pada RS di Kabupaten Banyumas.

\section{Metode Penelitian/Penulisan}

Penelitian ini dilakukan pada RS yang berada di wilayah Kabupaten Banyumas, Jawa Tengah. Populasi dari penelitian ini adalah pegawai di 7 RS yang berada di wilayah Kabupaten Banyumas. Pegawai rumah sakit yang diobservasi adalah pegawai manajerial (pimpinan RS/pimpinan unit Rekam Medis), dokter, dan staf unit rekam medis. Kabupaten Banyumas saat ini memiliki 23 RS. Dalam penelitian ini 23 RS tersebut dibagi menjadi 2 kelompok, yaitu kelompok RS yang telah mengimplementasikan RME dan kelompok RS yang belum mengimplementasikan RME, dari kelompok RS yang telah mengimplementasikan RME diambil 2 RS, yaitu RSUD Prof. Dr. Margono Soekarjo dan RSUD Banyumas. Sedangkan dari kelompok RS yang belum mengimplementasikan RME diambil 5 RS, yaitu RS Militer DKT Wijayakusuma, RSU Ananda, RSU
Bunda, RSU Sinar Kasih, dan RSU Dadi Keluarga.

Data yang digunakan dalam penelitian ini adalah data dari hasil penyebaran kuesioner yang telah diuji validitas dan reliabilitasnya. Pengambilan data dimulai dari tanggal 1 November s.d. 10 Desember 2016 di 7 RS yang ada di Kabupaten Banyumas.

Variabel dependen dalam penelitian ini adalah kemungkinan implementasi rekam medis elektronik (RME) pada rumah sakit (RS) di Kabupaten Banyumas. Variabel dependen skala biner, yaitu $0 \quad(\mathrm{Y}=0)$ untuk kemungkinan rumah sakit tidak mengimplementasikan RME dan 1 ( $\mathrm{Y}=1)$ untuk kemungkinan rumah sakit mengimplementasikan RME.

Variabel independen yang digunakan dalam penelitian ini adalah:

1. Finansial $(\mathrm{F})$

2. $\operatorname{SDM}(\mathrm{H})$

3. Teknologi (E)

4. Proses Perubahan $(\mathrm{C})$

5. Psikologis $(\mathrm{P})$

6. Infrastruktur (I)

7. Sosial (S)

8. Legal Formal (L)

9. Waktu (W)

10. Organisasi $(\mathrm{O})$

11. Tren TIK (T)

Variabel independen digunakan untuk mengukur persepsi responden 
terhadap faktor yang mempengaruhi implementasi RME di RS tempat mereka bekerja. Dengan pengkategorian persepsi sebagai berikut: 1 = tidak setuju, $2=$ kurang setuju, 3 = setuju, dan $4=$ sangat setuju, kecuali untuk variabel psikologis. Persepsi pada variabel psikologis dikategorikan sebagai berikut: 1 = sangat setuju, $2=$ setuju, 3 = kurang setuju, dan 4 = tidak setuju.

Regresi logistik biner adalah uji statistik yang digunakan untuk menjelaskan hubungan antara variabel respon yang berupa data kualitatif (data dengan skala nominal atau ordinal) dimana variabel respon bersifat dikotomus dan variabel tersebut hanya mempunyai dua kategori saja, yaitu kategori kejadian sukses $(\mathrm{Y}=1)$ dan kategori kejadian gagal $(\mathrm{Y}=0)$ dengan variabel bebas yang berupa data berskala interval dan atau kategorik. Model yang dapat digunakan untuk regresi logistik biner adalah model logit, dimana sifat yang tertuang dalam peluang kumulatif sehingga cumulative logit models merupakan model yang dapat dibandingkan dengan peluang kumulatif yaitu peluang kurang dari atau sama dengan kategori respon ke-r pada $p$ variabel prediktor yang dinyatakan dalam vektor $\mathrm{x}_{\mathrm{i}}$ adalah $\mathrm{P}\left(\mathrm{Y} \leq \mathrm{r} \mid \mathrm{x}_{\mathrm{i}}\right)$, dengan peluang lebih besar dari kategori respon ke-r pada $\mathrm{p}$ variabel prediktor $\mathrm{P}\left(\mathrm{Y}>\mathrm{r} \mid \mathrm{x}_{\mathrm{i}}\right)$ (Hosmer dan Lemeshow, 2000).

Peluang kumulatif $\mathrm{P}\left(\mathrm{Y} \leq \mathrm{r} \mid \mathrm{x}_{\mathrm{i}}\right)$

didefinisikan sebagai berikut:

$\left.\mathrm{P}\langle\mathrm{Y} \leq \mathrm{r}| \mathrm{x}_{\mathrm{i}}\right)=\pi(\mathrm{x})=\frac{\exp \left(\beta_{0 \mathrm{r}}+\sum_{\mathrm{k}=1}^{\mathrm{p}} \beta_{\mathrm{k}} \mathrm{x}_{\mathrm{ik}}\right)}{1+\exp \left(\beta_{0 \mathrm{r}}+\sum_{\mathrm{k}=1}^{\mathrm{p}} \beta_{\mathrm{k}} \mathrm{x}_{\mathrm{ik}}\right)}$

dimana $x_{i}=\left(x_{i 1}, x_{i 2}, \ldots, x_{i p}\right)$ merupakan nilai pengamatan $\mathrm{ke}-\mathrm{i}(\mathrm{i}=1,2, \ldots, \mathrm{n})$ dari setiap variabel $\mathrm{p}$ variabel prediktor (Agresti, 1990.).

Pendugaan parameter regresi dilakukan dengan cara menguraikannya menggunakan transformasi logit dari $\mathrm{P}\left(\mathrm{Y} \leq \mathrm{r} \mid \mathrm{x}_{\mathrm{i}}\right)$.

$$
\text { Logit } \mathrm{P}\left(\mathrm{Y} \leq \mathrm{r} \mid \mathrm{x}_{\mathrm{i}}\right)=\ln \left(\frac{\mathrm{P}\left(\mathrm{Y} \leq \mathrm{r}\left|\mathrm{x}_{\mathrm{i}}\right\rangle\right.}{1-\mathrm{P}\left(\mathrm{Y} \leq \mathrm{r} \mid \mathrm{x}_{\mathrm{i}}\right)}\right)
$$

Persamaan 3 didapatkan dengan mensubsitusikan persamaan 1 dan persamaan 2 .

Logit $\mathrm{P}\left(Y \leq r \mid x_{i}\right)=\beta_{0 \mathrm{r}}+\sum_{\mathrm{k}=1}^{p} \beta_{k} x_{\mathrm{ik}} \ldots$

dengan nilai $\beta_{\mathrm{k}}$ untuk setiap $\mathrm{k}=1,2, \ldots, \mathrm{p}$ pada setiap model regresi logistik ordinal adalah sama.

Model yang diperoleh perlu dilakukan uji signifikansi pada koefisien $\beta$ terhadap variabel respon, yaitu dengan uji serentak dan uji parsial. Uji serentak dilakukan untuk memeriksa kemaknaan koefisien $\beta$ terhadap variabel respon secara bersama-sama dengan menggunakan statistik uji. 
Hipotesis :

$$
\mathrm{H}_{0}: \beta_{1}=\beta_{2}=\ldots=\beta_{\mathrm{k}}=0
$$

$\mathrm{H}_{1}$ : paling sedikit ada satu $\beta_{\mathrm{k}} \neq 0$

$$
\mathrm{k}=1,2, \ldots, \mathrm{p}
$$

Statistik uji yang digunakan adalah statistik uji $\mathrm{G}$ atau Likelihood Ratio Test.

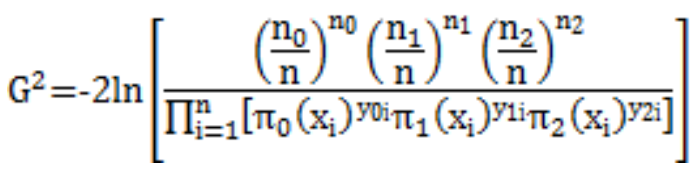

dimana,

$$
\begin{aligned}
& n_{0}=\sum_{i=1}^{n} y_{0 i}, \mathrm{n}_{1}=\sum_{i=1}^{n} y_{1 i}, \\
& n_{2}=\sum_{i=1}^{n} y_{2 i}, \mathrm{n}=\mathrm{n}_{0}+\mathrm{n}_{1}+\mathrm{n}_{2}
\end{aligned}
$$

Daerah penolakan $\mathrm{H}_{0}$ adalah jika $G^{2}=\chi_{(\alpha, v)}^{2}$ dengan derajat bebas $\mathrm{v}$ atau nilai $p$-value $<\alpha$. Statistik uji G mengikuti distribusi Chi-square dengan derajat bebas $\mathrm{p}$.

Uji parsial dilakukan untuk memeriksa kemaknaan koefisien $\beta$ secara parsial dengan menggunakan statistik uji.

$$
\begin{aligned}
& \mathrm{H}_{0}: \beta_{\mathrm{k}}=0 \\
& \mathrm{H}_{1}: \beta_{\mathrm{k}} \neq 0 ; \mathrm{k}=1,2, \ldots, \mathrm{p}
\end{aligned}
$$

Statistik uji yang digunakan adalah statistik uji Wald.

$$
\mathrm{W}=\frac{\beta_{k}}{\operatorname{SE}\left(\beta_{k}\right)}
$$

Daerah penolakan $\mathrm{H}_{0} \quad$ adalah $|W|>Z_{\alpha / 2}$ atau $W^{2}>\chi^{2}(\alpha, v)$ dengan derajat bebas $\mathrm{v}$ atau nilai $\mathrm{p}$-value $<\alpha$. (Hosmer dan Lemeshow, 2000).
Interpretasi koefisien parameter dari suatu model regresi logistik adalah inferensi dan pengambilan kesimpulan berdasarkan pada koefisien parameter. Koefisien menggambarkan slope atau perubahan pada variabel respon perunit untuk setiap perubahan variabel prediktor. Interpretasi koefisien parameter ini menyangkut dua hal, yaitu :

1. Perkiraan mengenai hubungan fungsional antara variabel respon dengan variabel prediktor.

2. Menentukan pengaruh dari setiap unit perubahan variabel prediktor terhadap variabel respon.

Untuk melakukan interprestasi ini maka digunakan odds ratio. Odds sendiri dapat diartikan sebagai rasio peluang kejadian sukses dengan kejadian tidak sukses dari peubah respon. Rasio odds mengindikasikan seberapa lebih mungkin munculnya kejadian sukses pada suatu kelompok dibandingkan dengan kelompok lainnya. Rasio odds didefinisikan sebagai:

$\psi=\exp \left\lfloor\beta_{j}\left(x_{1}-x_{2}\right)\right\rfloor$

Risiko $\psi=1, X=x 1$ sama dengan $X=x 2$ untuk menghasilkan $\mathrm{Y}=\mathrm{q}$. Bila $1<\psi<\infty$ maka $\mathrm{X}=\mathrm{x} 1$ memiliki risiko lebih tinggi $\psi$ kali dibandingkan $\mathrm{X}=\mathrm{x} 2$ untuk menghasilkan $\mathrm{Y}=\mathrm{q}$, dan sebaliknya $0<\psi<1, X=x 1$ memiliki 
risiko lebih tinggi $1 / \psi$ kali dibandingkan $\mathrm{X}=\mathrm{x} 2$ untuk menghasilkan $\mathrm{Y}=\mathrm{q}$.

\section{Pembahasan}

Kabupaten banyumas saat ini memiliki 23 Rumah Sakit dengan rincian 3 RSUD, 1 RSU Militer, 6 RS Khusus, dan 13 RSU Swasta. Dari hasil survey awal yang telah dilakukan pada bulan Februari 2016 dengan cara wawancara singkat dengan bagian administrasi dan bagian rekam medis diperoleh informasi bahwa terdapat 4 RS (2 RSUD, 1 RSK, 1 RSU Swasta) yang telah menggunakan RME dalam setahun terakhir.

Berdasarkan populasi yang ada, didapatkan sampel sebanyak 146 responden. Setelah melakukan pengambilan data terhadap sampel, maka langkah selanjutnya adalah melakukan analisis regresi logistik yang dimulai dari melakukan uji serentak.

\section{Pengujian Serentak}

Pengujian serentak dilakukan dengan metode backward, yaitu dimulai dari memasukkan sebelas variabel terlebih dahulu, kemudian dengan tingkat signifikansi $\alpha=10 \%$ secara bertahap dikurangi/dieliminasi satu per satu variabelnya hingga tersisa variabel independen yang signifikan saja. Metode backward digunakan karena diduga semua variabel independen yang ada mempengaruhi variabel dependen.
Hipotesis:

$\mathrm{H}_{0}: \beta_{1}=\beta_{2}=\ldots=\beta_{11}=0$ (tidak ada pengaruh antara finansial, SDM, teknologi, proses perubahan, psikologi, infrastruktur, sosial, legal, waktu, organisasi, dan tren TIK terhadap implementasi RME di RS)

$\mathrm{H}_{1}$ : paling sedikit ada satu $\beta_{\mathrm{k}} \neq 0$; (ada pengaruh antara finansial, SDM, teknologi, proses perubahan, psikologi, infrastruktur, sosial, legal, waktu, organisasi, dan tren TIK terhadap implementasi RME pada di RS)

dengan $\mathrm{k}=1,2, \ldots, 11$

Berdasarkan hasil pengolahan data, ketika variabel independen tidak dimasukkan kedalam model diperoleh nilai Chi-Square $\left(\chi^{2}\right)=174,10$ dengan probabilitas 0,05 dan degree of freedom (df) $\mathrm{df}=\mathrm{n}-1=145$, serta dari proses pengolahan data tersebut juga diperoleh nilai -2 Log likelihood $(-2 L L)=202,372$. Karena nilai $-2 \mathrm{LL}>\chi^{2}$, maka menunjukan bahwa model sebelum memasukkan variabel independen adalah tidak fit dengan data. Oleh sebab itu analisis dapat dilanjutkan dengan memasukkan variabel independen kedalam model.

Saat variabel independen dimasukkan kedalam model diperoleh nilai $-2 \mathrm{LL}=146,570$ serta nilai chisquare $\left(\chi^{2}\right)=163,12$, dengan probabilitas 
0,05 dan $\mathrm{df}=146-11-1=134$. Karena nilai $-2 \mathrm{LL}<\chi^{2}$, maka menunjukkan bahwa model dengan memasukkan variabel independen adalah fit dengan data.

Tabel 1. Tabel Omnimbus Test of Model Coeficients

\begin{tabular}{|l|c|c|c|}
\hline & Chi-square & df & Sig. \\
\hline Step & $-0,709$ & 1 & 0,400 \\
\hline Block & 55,801 & 8 & 0,000 \\
\hline Model & 55,801 & 8 & 0,000 \\
\hline
\end{tabular}

Dari tabel omnimbus test seperti pada Tabel 1 didapatkan nilai sig of $\chi^{2}=0,000<0,1$ maka $\mathrm{H}_{0}$ ditolak. Hal ini menunjukkan bahwa penambahan variabel independen dapat memberikan pengaruh nyata terhadap model, atau dengan kata lain model dinyatakan FIT, atau dapat disimpulkan bahwa ada pengaruh antara faktor finansial, SDM, teknologi, proses perubahan, psikologi, infrastruktur, sosial, legal, waktu, organisasi, dan tren TIK terhadap implementasi RME pada suatu RS.

\section{Uji Kesesuaian Model}

Untuk menentukan apakah model yang dibentuk sudah tepat atau tidak digunakan tabel Hosmer and Lemeshow Test seperti pada tabel 2. Dikatakan tepat apabila tidak ada perbedaan signifikan antara model dengan nilai observasinya.

Dari Tabel 2 didapatkan nilai signifikansi $0,311>0,1$ maka model dapat diterima dan pengujian hipotesis dapat dilakukan sebab tidak ada perbedaan signifikan antara model dengan nilai observasinya

Tabel 2. Tabel Hosmer and Lemeshow Test

\begin{tabular}{|c|c|c|c|}
\hline Step & Chi-Square & Df & Sig. \\
\hline 1 & 8,793 & 8 & 0,360 \\
\hline 2 & 9,372 & 8 & 0,312 \\
\hline 3 & 10,155 & 8 & 0,254 \\
\hline 4 & 8,257 & 7 & 0,311 \\
\hline
\end{tabular}

Analisis Parsial

Pengujian ini dilakukan untuk memeriksa kemaknaan variabel independen (koefisien $\beta$ ) secara parsial terhadap variabel dependen dengan menggunakan statistik uji Wald.

Hipotesis

$$
\begin{aligned}
& \mathrm{H}_{0}: \beta_{\mathrm{k}}=0 \\
& \mathrm{H}_{1}: \beta_{\mathrm{k}} \neq 0 ; \mathrm{k}=1,2, \ldots, 11
\end{aligned}
$$

Pada uji parsial diharapkan Ho akan ditolak sehingga variabel yang sedang diuji masuk ke dalam model.

Berdasarkan data pada Tabel 3 dengan signifikansi $\alpha=0,1$ diketahui bahwa terdapat delapan variabel independen yang signifikan berpengaruh terhadap implementasi RME pada RS yaitu finansial, SDM, proses perubahan, psikologi, legal, waktu, organisasi, dan tren TIK. Kedelapan variabel independen tersebut memiliki nilai signifikasi yang lebih kecil dari $\alpha$. Hasil perhitungan tersebut menunjukkan bahwa variabel teknologi, sosial, dan infrastruktur tidak signifikan berpengaruh terhadap implementasi RME di RS. 
Tabel 3. Tabel "Variables in The Equation"

\begin{tabular}{|c|r|c|c|c|c|c|c|c|}
\hline & \multicolumn{1}{|c|}{ B } & S.E. & Wald & df & Sig. & \multirow{2}{*}{$\operatorname{Exp}(\mathrm{B})$} & \multicolumn{2}{|c|}{$90.0 \%$ C.I.for Exp(B) } \\
\cline { 7 - 9 } & & & & & & & Lower & Upper \\
\hline F & 0,729 & 0.410 & 3,154 & 1 & 0,076 & 2,072 & 1,055 & 4,069 \\
\hline H & $-1,046$ & 0,490 & 4,562 & 1 & 0,033 & 0,351 & 0,157 & 0,786 \\
\hline C & $-1,055$ & 0,540 & 3,821 & 1 & 0,051 & 0,348 & 0,143 & 0,846 \\
\hline P & 1,122 & 0,496 & 5,106 & 1 & 0,024 & 3,070 & 1,357 & 6,948 \\
\hline L & $-1,160$ & 0,574 & 4,086 & 1 & 0,043 & 0,313 & 0,122 & 0,806 \\
\hline W & $-1,246$ & 0.409 & 9,258 & 1 & 0,002 & 0,288 & 0,147 & 0,564 \\
\hline O & 1,145 & 0,337 & 11,566 & 1 & 0,001 & 3,142 & 1,806 & 5,466 \\
\hline T & 2,222 & 0,547 & 16,513 & 1 & 0,000 & 9,229 & 3,754 & 22,688 \\
\hline Constant & $-1,625$ & 2,425 & 0,449 & 1 & 0,503 & 0,197 & & \\
\hline
\end{tabular}

Berdasarkan uji parsial tersebut maka model yang terbentuk adalah :

$$
\pi(x)=\frac{e^{f[x]}}{1+e^{f(x)}}
$$

Dengan

$f(x)=-1,6+0,7 F-1,1 \mathrm{H}-1,1 \mathrm{C}+1,1 \mathrm{P}-1,2 \mathrm{~L}-1,3 \mathrm{~W}+1,2 \mathrm{O}+2,2 \mathrm{~T}$

Contoh penggunaan persamaan (7) adalah sebagai berikut. Misalkan sebuah RS kelas $\mathrm{B}(\mathrm{O}=3)$ yang selalu mengikuti perkembangan jaman/TIK $\quad(\mathrm{T}=3)$ dipersepsikan memiliki kemampuan finansial yang baik $(\mathrm{F}=3)$, memiliki SDM yang mampu mengoperasikan komputer dengan baik dan sudah memiliki pengetahuan tentang RME yang baik $(\mathrm{H}=3)$. Pada RS tersebut juga diketahui hanya sebagian kecil SDM yang menolak untuk mengimplementasikan $\mathrm{RME}(\mathrm{P}=3)$. Manajemen menyadari bahwa untuk mempersiapkan aplikasi RME hingga dapat diimplementasikan membutuhkan waktu yang lama $(\mathrm{W}=2)$. Misalkan pula, sambil menunggu waktu, manajemen mempersiapkan berbagai macam prosedur dan pelatihan agar implementasi RME dapat berjalan dengan lancar $(C=3)$, termasuk didalamnya antisipasi dari legal hukum yang ada $(\mathrm{L}=3)$. Berdasarkan contoh tersebut, jika dimasukkan kedalam persamaan (7) didapat nilai $\pi(\mathrm{x})=0,852$. Oleh karena $\pi(\mathrm{x})>0,5$ maka nilai Predicted Group Membership dari contoh masuk dalam kategori RS yang telah mengimplementasikan RME.

Persentase ketepatan persamaan (7) dalam memprediksi adalah 77,4 \% seperti yang terlihat pada Tabel 4. Karena penelitian ini merupakan penelitian sosial maka ketepatan prediksi model sebesar $77,4 \%$ masih dianggap baik. 
Tabel 4. Classification Table

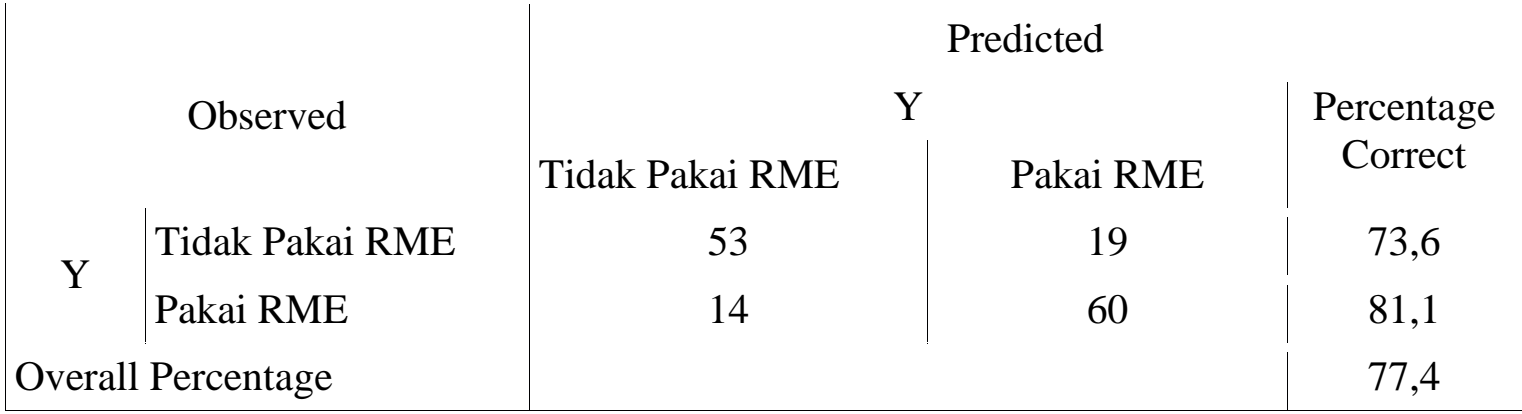

\section{Interpretasi Odds Ratio}

Besarnya pengaruh setiap variabel yang signifikan ditunjukkan dengan nilai EXP (B) atau disebut juga ODDS RATIO (OR) seperti yang tedapat pada tabel 3 . Nilai odds ratio dapat diinterpretasikan sebagai berikut.

1. Faktor finansial memiliki OR sebesar 2,072, artinya RS yang dipersepsikan memiliki kemampuan finansial yang baik, memiliki peluang untuk dapat mengimplementasikan RME di RS sebanyak 2,072 kali daripada RS yang dipersepsikan memiliki finansial selain baik.

2. Faktor SDM memiliki OR 0,351, artinya RS yang dipersepsikan memiliki sedikit SDM yang kemampuan operasional komputer dan pengetahuan tentang RME tidak baik, memiliki peluang sedikit lebih baik untuk mengimplementasikan RME daripada RS yang masih memiliki banyak SDM dengan kemampuan operasional komputer dan pengetahuan tentang RME selain baik.

3. RS yang dalam implementasi RME haruslah terlebih dahulu melakukan sebuah perencanaan, salah satunya adalah bagaimana cara melakukan proses perubahan. Proses perubahan merupakan salah satu faktor yang dipersepsikan oleh responden menghambat implementasi RME pada RS. RS yang merencanakan proses perubahan dengan baik memiliki peluang sedikit lebih baik $(\mathrm{OR}=0,348)$ untuk dapat mengimplementasikan RME di RS daripada RS yang tidak memiliki rencana proses perubahan.

4. Faktor psikologis dalam hal ini adalah resistensi pengguna RME. RS yang dipersepsi dapat mengatasi faktor psikologis pengguna RME dengan baik memiliki peluang 3,070 kali untuk mengimplementasikan RME pada RS.

5. Regulasi dan legalitas tentang RME memiliki pengaruh yang kecil 
$(\mathrm{OR}=0,313) \quad$ terhadap implementasi RME di RS.

6. Waktu dipersepsikan oleh responden merupakan salah satu faktor yang mempengaruhi implementasi RME pada RS. Waktu dipersepsikan oleh para responden sebagai faktor penghambat implementasi RME. RS yang dipersepsikan dapat mengatasi faktor waktu memiliki peluang sedikit lebih baik $(\mathrm{OR}=0,288)$ untuk dapat mengimplementasikan RME pada RS.

7. RS dengan organisasi yang lebih baik memiliki peluang 3,142 kali lebih mudah untuk mengimplementasikan RME pada RS

8. RS yang selalu mengikuti perkembangan tren TIK memiliki peluang 9,229 kali lebih mudah untuk mengimplementasikan RME pada RS.

Berdasarkan uraian diatas diketahui bahwa secara statistik faktor tren TIK, organisasi, faktor psikologis, dan faktor finansial merupakan faktor yang memiliki pengaruh paling besar dengan OR berturut-turut 9,229, 3,124, 3,070 , dan 2,072.

\section{Kesimpulan}

Berdasarkan hasil analisis menggunakan regresi logistik didapatkan delapan faktor yang secara statistik berpengaruh terhadap implementasi RME pada RS di Kabupaten Banyumas. Adapun kedelapan faktor tersebut adalah faktor finansial, faktor SDM, faktor proses perubahan, faktor psikologi, faktor legal, faktor waktu, faktor organisasi, dan tren TIK. Faktor teknologi, infrastruktur, dan sosial adalah faktor yang tidak berpengaruh terhadap implementasi RME pada RS.

Dalam penelitian ini juga dapat dibuktikan bahwa faktor tren TIK merupakan variabel baru yang secara statistik berpengaruh terhadap implementasi RME pada RS.

\section{Saran}

Pada penelitian selanjutnya disarankan untuk dapat dilakukan kajian lebih mendalam terhadap faktor teknologi, infrastruktur, dan sosial. Pada penelitian ini ketiga faktor tersebut dipersepsikan oleh para responden tidak memiliki pengaruh yang signifikan terhadap implementasi RME pada RS di Kabupaten Banyumas, padahal pada penelitian terdahulu ketiga faktor tersebut berpengaruh. Pada penelitian ini, faktor tren TIK merupakan variabel baru yang secara statistik berpengaruh terhadap implementasi RME pada RS. Oleh sebab itu, disarankan untuk dapat melakukan penelitian lebih mendalam terhadap variabel tren TIK.

\section{Pustaka}

Agresti, A. (1990). Categorical Data Analysis. New York: John Wiley \& Sons, Inc. 
Benson, A. C., 2011, Assessing Barriers to Adoption of Hospital Information Systems in Nigeria. Journal of Global Health Care Systems, 1(3), 1-33.

Boonstra, A., \& Broekhuis, M., 2010, Barriers to the acceptance of electronic medical records by physicians from systematic review to taxonomy and interventions. BioMed Central (BMC), 10:231.

Butt, F. S., Mahum, R., Zia, A., Nawab, S., \& Shad, S. A., 2014, Barriers in implementation of electronic medical records in pakistan. Science International - Lahore, 26(4), 16811686.

Djalil, S. A., 2005, Teknologi Informasi Untuk Kesehatan Sebagai Komunikasi Informasi Efektif Bagi Daerah. Simposium Nasional "Membangun Era Informasi melalui Sistem Rekam Elektronik (RKE) dalam Manajemen Informasi Kesehatan di Indonesia"; diselenggarakan oleh Ditjen Pelayanan Medik - Departemen Kesehatan Jakarta pada 23 Agustus 2005

Granlien, M. S., \& Hertzum, M., 2012, Barriers to the Adoption and Use of an Electronic Medication Record. Electronic Journal Information System Evaluation, 15(2), 216-227.

Hanafiah, J. M., \& Amir, A., 1999, Etika Kedokteran \& Hukum Kesehatan (3rd ed.). Jakarta: Buku Kedokteran EGC.

Handiwidjojo, W., 2009, Rekam medis elektronik. EKSIS, 2, 36-41.

Hasanain, R. A., \& Cooper, H., 2014, Solutions to Overcome Technical and Social Barriers to Electronic Health Records Implementation in Saudi Public and Private Hospitals. Journal of Health Informatics in Developing Countries, 8(1), 46-63.
Hassan, N. H., Rahim, F. A., \& Ismail, Z., 2010, A Review of Barriers in Adopting Healthcare Information System. Electronic Journal of Computer Science and Information Technology (ejCSiT), 2, 1-5.

Hosmer, DW., Lemeshow, S., 2000. Applied Logistic Regression. New York: John Wiley \& Sons, Inc.

Khalifa, M., 2013, Barriers to Health Information Systems and Electronic Medical Records Implementation. A Field Study of Saudi Arabian Hospitals. Procedia - Procedia Computer Science, 21, 335-342.

Pemerintah Kota Bogor, 2013, Penerapan Teknologi Informasi dan Komunikasi Untuk Mendukung Pengembangan e-Goverment Pemerintah Kota Bogor 2014 - 2018. http://kominfo.kotabogor.go.id/asset /file/sop/penerapan-tik-20142018.pdf. Diakses pada tanggal 19 Januari 2017.

Subkhan, Edi., 2011, Reposisi Tren ICT dalam Bidang Kajian Teknologi Pendidikan. Masyarakat Telematika dan Informasi: Jurnal Penelitian Teknologi Informasi dan Komunikasi, 2, 89-113 